\title{
Prediction of Chiller Power Consumption: An Entropy Generation Approach
}

\section{Jayaprakash Saththasivam \& Kim Choon Ng}

To cite this article: Jayaprakash Saththasivam \& Kim Choon Ng (2016): Prediction of Chiller Power Consumption: An Entropy Generation Approach, Heat Transfer Engineering, DOI: 10.1080/01457632.2016.1194697

To link to this article: http://dx.doi.org/10.1080/01457632.2016.1194697

Accepted author version posted online: 21

Jun 2016.

Published online: 21 Jun 2016.

Submit your article to this journal $₫$

Џ Article views: 6

Q View related articles $๘$

View Crossmark data ¿ 


\section{ACCEPTED MANUSCRIPT}

\section{Prediction of Chiller Power Consumption: An Entropy Generation Approach Jayaprakash Saththasivam ${ }^{1,2}$ and Kim Choon $\mathrm{Ng}^{2,3}$}

${ }^{1}$ Qatar Environment and Energy Research Institute, Doha, Qatar

${ }^{2}$ Water Desalination and Reuse Center, King Abdullah University of Science and Technology, Saudi Arabia

${ }^{3}$ Department of Mechanical Engineering, National University of Singapore, Singapore ABSTRACT

Irreversibilities in each component of vapor compression chillers contribute to additional power consumption in chillers. In this study, chiller power consumption was predicted by computing the Carnot reversible work and entropy generated in every component of the chiller. Thermodynamic properties namely enthalpy and entropy of the entire refrigerant cycle were obtained by measuring the pressure and temperature at the inlet and outlet of each primary component of a $15 \mathrm{~kW} R 22$ water cooled scroll chiller. Entropy generation of each component was then calculated using the First and Second Laws of Thermodynamics. Good correlation was found between the measured and computed chiller power consumption. This irreversibility analysis can be also effectively used as a performance monitoring tool in vapor compression chillers as higher entropy generation is anticipated during faulty operations.

Address correspondence to Professor Kim Choon Ng, Department of Mechanical Engineering, National University of Singapore, 9 Engineering Drive 1 Singapore, 117576. E-mail: mpengkc@nus.edu.sg 


\section{ACCEPTED MANUSCRIPT}

\section{INTRODUCTION}

Vapor compression (VC) chillers are widely used in the air conditioning and refrigeration industries. In contrast to ideal vapor compression cycle that operates isothermally and isentropically, actual vapor compression chiller suffers from several irreversibilities that are mainly governed by fluid friction (pressure drop), finite rate heat transfer and heat leaks to and from the surroundings [1-8]. Pressure drops at the condenser and the evaporator as well as nonisentropic compression and expansion by the compressor and the expansion valve contribute to entropy generation in a VC system. The increase in entropy generation is further amplified during a faulty condition. These irreversibilities contribute to higher power consumption in chiller.

In this study, we attempted to predict chiller power consumption using entropy generation approach. Entropy generation for each component of a chiller namely (i) evaporator (ii) compressor (iii) condenser (iv) expansion valve and (v) refrigerant piping were calculated based on the local temperature and pressure measurements. From the First and Second Laws of Thermodynamics, the entropy generation and loss work of the refrigeration cycle can be determined, thus enabling the prediction of the power consumption of chillers. This method can be effectively used to detect and diagnose faults in refrigeration system by monitoring the trends of entropy generated in the primary components of a chiller.

\section{ENTROPY GENERATION IN VAPOR COMPRESSION CHILLER}

For the calculation of entropy generation [1] for each key component of a VC chiller at steady state, the refrigerant mass flow rate was assumed to be constant throughout the cycle. 


\section{ACCEPTED MANUSCRIPT}

Energy balance and entropy balance equations were used to calculate the irreversibilities for each chiller component shown in Figure 1.

\section{Evaporator:}

First law Energy Balance:

$$
\begin{array}{ll}
\dot{Q}_{\text {evap }}(k W)= & \dot{Q}_{71} \\
=\dot{m}_{\text {ref }}\left(h_{1}-h_{7}\right) & \text { (1) }
\end{array}
$$

Second law Entropy Balance:

$$
\dot{S}_{g e n, 71}=\left(\frac{k W}{K}\right)=\dot{m}_{r e f}\left(s_{1}-s_{7}\right)-\frac{\dot{Q}_{\text {evap }}}{T_{R}}
$$

For water-cooled evaporator, $T_{R}$ is taken as the chilled water outlet temperature, $T_{C, \text { outlet }}$ using the extended boundary concept. Since, chilled water outlet temperature defines the chiller operating set point, therefore it is reasonable to extend the system boundary until the set point temperature.

Suction Line:

First law Energy Balance:

$$
\dot{\mathrm{Q}}_{12}(\mathrm{~kW})=\dot{\mathrm{m}}_{\mathrm{ref}}\left(\mathrm{h}_{2}-\mathrm{h}_{1}\right)
$$

Second law Entropy Balance: 


\section{ACCEPTED MANUSCRIPT}

$$
\dot{\mathrm{S}}_{\mathrm{gen}, 12}\left(\frac{\mathrm{kW}}{\mathrm{K}}\right)=\dot{\mathrm{m}}_{\mathrm{ref}}\left(\mathrm{s}_{2}-\mathrm{s}_{1}\right)-\frac{\dot{\mathrm{Q}}_{12}}{\mathrm{~T}_{\mathrm{ambient}}}
$$

\section{Compressor:}

First law Energy Balance:

$$
\dot{\mathrm{Q}}_{23}(\mathrm{~kW})=\dot{\mathrm{m}}_{\mathrm{ref}}\left(\mathrm{h}_{3}-\mathrm{h}_{2}\right)+\dot{\mathrm{W}}_{23}
$$

Second law Entropy Balance:

$$
\dot{\mathrm{S}}_{\mathrm{gen}, 23}\left(\frac{\mathrm{kW}}{\mathrm{K}}\right)=\dot{\mathrm{m}}_{\mathrm{ref}}\left(\mathrm{s}_{3}-\mathrm{s}_{2}\right)-\frac{\dot{\mathrm{Q}}_{23}}{\mathrm{~T}_{\text {ambient }}}
$$

Discharge Line:

First law Energy Balance:

$$
\dot{\mathrm{Q}}_{34}(\mathrm{~kW})=\dot{\mathrm{m}}_{\mathrm{ref}}\left(\mathrm{h}_{4}-\mathrm{h}_{3}\right)
$$

Second law Entropy Balance:

$$
\dot{\mathrm{S}}_{\text {gen,34 }}\left(\frac{\mathrm{kW}}{\mathrm{K}}\right)=\dot{\mathrm{m}}_{\mathrm{ref}}\left(\mathrm{s}_{4}-\mathrm{s}_{3}\right)-\frac{\dot{\mathrm{Q}}_{34}}{\mathrm{~T}_{\mathrm{ambient}}}
$$

\section{Condenser:}

First law Energy Balance:

$$
\dot{\mathrm{Q}}_{\text {Cond }}=\dot{\mathrm{Q}}_{45}(\mathrm{~kW})=\dot{\mathrm{m}}_{\mathrm{ref}}\left(\mathrm{h}_{5}-\mathrm{h}_{4}\right)
$$




\section{ACCEPTED MANUSCRIPT}

Second law Entropy Balance:

$$
\dot{\mathrm{S}}_{\mathrm{gen}, 45}\left(\frac{\mathrm{kW}}{\mathrm{K}}\right)=\dot{\mathrm{m}}_{\mathrm{ref}}\left(\mathrm{s}_{5}-\mathrm{s}_{4}\right)-\frac{\dot{\mathrm{Q}}_{45}}{\mathrm{~T}_{\text {Cool }}}
$$

Using the concept of extended boundary, the heat sink temperature, $\mathrm{T}_{\mathrm{Cool}}$ is assumed as to be condenser inlet water temperature, $\mathrm{T}_{\mathrm{H}, \text { inlet }}$

Liquid Line:

First law Energy Balance:

$$
\dot{\mathrm{Q}}_{56}(\mathrm{~kW})=\dot{\mathrm{m}}_{\mathrm{ref}}\left(\mathrm{h}_{6}-\mathrm{h}_{5}\right)
$$

Second law Entropy Balance:

$$
\dot{\mathrm{S}}_{\mathrm{gen}, 56}\left(\frac{\mathrm{kW}}{\mathrm{K}}\right)=\dot{\mathrm{m}}_{\mathrm{ref}}\left(\mathrm{s}_{6}-\mathrm{s}_{5}\right)-\frac{\dot{\mathrm{Q}}_{56}}{\mathrm{~T}_{\mathrm{ambient}}}
$$

Expansion Valve:

First law Energy Balance:

$$
\dot{\mathrm{Q}}_{67}(\mathrm{~kW})=\dot{\mathrm{m}}_{\mathrm{ref}}\left(\mathrm{h}_{6}-\mathrm{h}_{7}\right)=0 \text { (isenthalpic expansion) }
$$

Second law Entropy Balance:

$$
\dot{\mathrm{S}}_{\mathrm{gen}, 67}\left(\frac{\mathrm{kW}}{\mathrm{K}}\right)=\dot{\mathrm{m}}_{\mathrm{ref}}\left(\mathrm{s}_{7}-\mathrm{s}_{6}\right)
$$




\section{ACCEPTED MANUSCRIPT}

The total entropy generation, $\dot{\mathrm{S}}_{\text {gen,Total }}$ of the refrigerant circuit can be obtained by summing all the entropy generations of each component.

$$
\begin{aligned}
\dot{\mathrm{S}}_{\text {gen,Total }}\left(\frac{\mathrm{kW}}{\mathrm{K}}\right) & \\
= & \dot{\mathrm{S}}_{\text {gen,Evaporator }}+\dot{\mathrm{S}}_{\text {gen,Suction Line }}+\dot{\mathrm{S}}_{\text {gen,Compressor }}+\dot{\mathrm{S}}_{\text {gen,Discharge Line }} \\
& +\dot{\mathrm{S}}_{\text {gen,Condenser }}+\dot{\mathrm{S}}_{\text {gen,Liquid Line }}+\dot{\mathrm{S}}_{\text {gen,Expansion valve }}
\end{aligned}
$$

\section{CARNOT COP AND CARNOT POWER}

As shown in Figure 2, the energy and entropy balance for Reverse Carnot cycle can be expressed as following:-

Energy Balance:

$$
\begin{gathered}
\mathrm{d} \dot{\mathrm{Q}}_{\text {Cond }}=\mathrm{d} \dot{\mathrm{Q}}_{\text {Evap }}+\mathrm{d} \dot{\mathrm{W}} \\
\dot{\mathrm{Q}}_{\text {Cond }}=\dot{\mathrm{m}}_{\mathrm{h}} \mathrm{Cp}_{\mathrm{h}} \mathrm{dT}_{\mathrm{H}} \\
\mathrm{d} \dot{\mathrm{Q}}_{\text {Evap }}=\dot{\mathrm{m}}_{\mathrm{c}} \mathrm{Cp}_{\mathrm{c}} \mathrm{dT}_{\mathrm{C}}
\end{gathered}
$$

Entropy Balance:

$$
\mathrm{d} \dot{\mathrm{s}}=\frac{\mathrm{d} \dot{\mathrm{Q}}_{\text {Cond }}}{\mathrm{T}_{\mathrm{H}}}-\frac{\mathrm{d} \dot{\mathrm{Q}}_{\text {Evap }}}{\mathrm{T}_{\mathrm{C}}}=0
$$

Using Equation (17-19), it can be proved that 


\section{ACCEPTED MANUSCRIPT}

$$
\left(\dot{m}_{h} C p_{h}\right) \frac{d T_{H}}{T_{H}}+\left(\dot{m}_{c} C p_{c}\right) \frac{d T_{C}}{T_{C}}=0
$$

By integrating this equation, it can be shown that:

$$
T_{H}{ }^{\left(\dot{m}_{h} C p_{h}\right)} T_{C}{ }^{\left(\dot{m}_{c} C p_{c}\right)}=\text { Constant }
$$

By using the inlet temperature conditions, the constant value of Equation 3.34 can be obtained. For a reverse Carnot cycle, the following equation can be used to determine the coolant temperatures:

$$
T_{H}{ }^{\left(\dot{m}_{h} C p_{h}\right)} T_{C}{ }^{\left(\dot{m}_{c} C p_{c}\right)}=T_{H, \text { inlet }}{ }^{\left(\dot{m}_{h} C p_{h}\right)} T_{C, \text { inlet }}{ }^{\left(\dot{m}_{c} C p_{c}\right)}
$$

For instance, at a specified $T_{H \text { Inlet, }} T_{C \text { Inlet }}$, and $T_{C \text { outlet, }}$ the condenser leaving water temperature ( $\left.T_{H \text { outlet }}\right)$ of a reverse Carnot cycle [2] can be obtained as:

$$
T_{H, \text { outlet Carnot }}=\left[\left(\frac{T_{C, \text { inlet }}}{T_{C, \text { outlet }}}\right)^{\frac{\dot{m}_{c} C p_{c}}{\dot{m}_{h} C p_{h}}}\right] T_{H, \text { inlet }}
$$

Therefore the Carnot Power (reversible work) can be obtained using the computed $T_{H, o u t l e t}$ and other prescribed coolant temperatures. From Equation 16,

$$
\dot{W}_{\text {reversible }}=\dot{m}_{h} C p_{h}\left(T_{H, \text { outlet Carnot }}-T_{H, \text { inlet }}\right)-\dot{m}_{c} C p_{c}\left(T_{C, \text { inlet }}-T_{C, \text { outlet }}\right)
$$

\section{PREDICTION OF CHILLER POWER CONSUMPTION}

Chiller power can be computed by summing the reversible Carnot power and total entropy generation. 


\section{ACCEPTED MANUSCRIPT}

$$
\begin{aligned}
& \dot{W}_{\text {comp }}=\dot{W}_{\text {reversible }}+\dot{W}_{\text {lost work }} \\
& \dot{W}_{\text {lost work }}=\dot{S}_{\text {gen,Total }} T_{\text {ambient }}
\end{aligned}
$$

\section{EXPERIMENTAL TEST RIG}

The assembled coolant system consisted of two mixing chambers, a cooling tower, a water tank, two flow meters, five resistance temperature detectors (RTDs), six positive displacement water pumps and associated valves, four modulating valves, strainers, air vents, flow switches and a network of water pipes. The desired set point of the leaving chilled water temperature and the entering cooling water temperature were obtained by mixing the water in respective cold and hot mixing chambers using four units of electric linear modulating valves (PID 1 - 4). The cold and hot chambers served the evaporator and condenser respectively. The chambers were designed with staggered internal baffles to enhance the mixing process. The hot and cold sources of the cold mixing chamber were supplied from the cooling tower return water (using pump 5) and the leaving chilled water from the evaporator respectively. These streams were controlled using PID 2 and PID 4. On the other hand, the PID 1 and PID 3 regulated the cold and hot streams of the hot mixing chamber. The cold stream for this chamber was supplied from the cooling tower return water using pump 3 while the hot stream was obtained from the leaving cooling water from the condenser. The PID 1-4 electric linear modulating globe valves were controlled using PID controllers that were developed using LabView 8.6. These controllers played a critical role in maintaining the coolant temperatures to within $0.20 \mathrm{~K}$ of the desired set 


\section{ACCEPTED MANUSCRIPT}

points. For the purpose of data acquisition and flow controls of the mixing chambers, five units of 4 wire RTD were used to measure the following: - (i) Chilled water leaving temperature / Evaporator outlet water temperature (ii) Chilled water entering temperature/ Evaporator inlet water temperature (iii) Cooling water leaving temperature / Condenser outlet water temperature (iv) Cooling water entering temperature / Condenser inlet water temperature and (v) cooling tower return water temperature. These temperatures were data logged and used as inputs for the PID controllers. The outlet streams of the cold and hot mixing chambers supplied the coolants at the specified set point temperatures to the respective evaporator and condenser using pump 6 and 1. The flow rates of these feeds could be regulated using bypass valve 13 and 7 . Two electromagnetic DANFOSS MAGFLO flow meters, model MAG 5000 and 6000 (accuracy of $0.25 \%$ ) were used to measure the chilled and cooling water flow rates. The schematic of the coolant system is shown in Figure 3.

The refrigerant system consisted of a R22 scroll compressor, a water-cooled condenser, a direct-expansion water-cooled evaporator, an externally equalized thermostatic and electronic expansion valves, a variable speed drive, seven units of pressure transducers, seven units of 4 wire RTDs, a refrigerant flow meter, a liquid filter dryer unit, shut-off valves, a sight glass and solenoid valve. Extended details of this system are as following:-

a) Refrigerant: R22

b) Compressor: COPELAND Scroll compressor, model ZR81 KC-TFD-522, with a nominal 6.8 horsepower. 


\section{ACCEPTED MANUSCRIPT}

c) Evaporator: $15 \mathrm{~kW}$ Direct expansion evaporator; Shell and tube type (with R22 in the tube and water on the shell), 4 passes (refrigerant) with Stainless steel 304 tubes.

d) Condenser: Shell and tube type (with R22 on the shell and water inside the tube), 4 passes (water ) with Stainless steel 304 tubes

e) Electronic Expansion Valve: EMERSON PWM EX-2 EXV with EC2-39 Controller.

f) Variable Speed/Frequency Drive: Danfoss, VLT2875, $7.5 \mathrm{~kW}, 10 \mathrm{HP}, 16 \mathrm{~A}$, Three phases 380-460/380-480 VAC.

g) Refrigerant Flow meter: KROHNE,Model 29/RR/M9/es; Range: 36-360 L/hr; Accuracy: $1.6 \%$ F.S

h) Power Meter: HIOKI, Model 3184, measures the electrical power consumption of the whole chiller system, with an accuracy of $\pm 0.01 \mathrm{~kW}$.

i) Pressure Transducers: Low Pressure (Evaporator) measurements: Gems Sensors Pressure Transducer Model:1200BGB1001A3UA; Range : 0-10 barG , Accuracy: $0.5 \%$ F.S. High Pressure (Condenser) measurements: Gems Sensors Pressure Transducer Model: 1200BGB2501A3UA; Range : 0-25 barG, Accuracy: $0.5 \%$ F.S

j) Temperature Probes: 4 wire RTD, PT100, 1/3 DIN

The temperature and pressure transducers were installed at the following locations:- (i) compressor discharge line (TP1), (ii) condenser inlet (TP2), (iii) condenser outlet (TP3), (iv) 


\section{ACCEPTED MANUSCRIPT}

liquid line before expansion valve (TP4), (v) evaporator inlet (TP5), (vi) evaporator outlet (TP6) and (vii) compressor suction line (TP7). This schematic is shown in Figure 4.

\section{STEADY STATE ANALYSES}

In this study, leaving chilled water temperature $\left(T_{C, \text { outlet }}\right)$, entering cooling water temperature $\left(T_{H, \text { Inlet }}\right)$, and compressor frequency were used as operating test variables. The test matrix is shown in Table 1. A total of 20 different set points were used to capture both the full and part load performance of the chiller. The coolant set points were controlled using the PID controlled valves while the compressor speed were regulated using the variable speed drive. Deviations in the set points were kept to minimal using these high accuracy devices.

The specified set points along with cooling load and the overall system energy balance were used as steady state indicators of the chiller. The scroll chiller used in this study was assumed to be in a steady state if deviations in the steady indicators were below than their allowable tolerance for a minimum period of 15 minutes. The maximum allowable deviation for each steady indicator is as following:-

a) $\quad 0.2 \mathrm{~K}$ tolerance for the leaving chilled water temperature

b) $\quad 0.2 \mathrm{~K}$ tolerance for the entering cooling water temperature

c) $\quad 0.1 \mathrm{~Hz}$ tolerance for the compressor frequency

d) $5 \%$ tolerance in the cooling load for full load data and $7.7 \%$ tolerance at a part load of $70 \%$ 


\section{ACCEPTED MANUSCRIPT}

e) $5 \%$ tolerance in the overall system energy balance for full load data and $7.7 \%$ tolerance at a part load of $70 \%$

f) $5 \%$ tolerance in both the rated cooling water and chilled water flow rate. The rated cooling water and the chilled water flow rates are $48.7 \mathrm{lpm}$ and $38.6 \mathrm{lpm}$ respectively.

\section{RESULTS AND DISCUSSION}

Based on the Second Law of Thermodynamics derivations as described earlier, the entropy generations of the key chiller components were computed based on refrigerant pressures

and temperatures. The entropy and enthalpy values were obtained from NIST Refprop using these measured parameters. Table 2 shows the calculated entropy generations for all the chiller components at twenty different operating conditions. Table 3 compares the actual chiller power consumption (measured using energy meter) against the computed power consumption derived from Equation 25. The prediction accuracy is also shown in Figure 5. These data show that the computed power consumption closely matches the measured chiller power. In other words, it is possible to estimate the actual power consumption by computing the entropy generated in each primary components of a chiller.

As the proposed method is able to compute the loss work of each component, it can be effectively used as a performance monitoring tool by trending this parameter over a time frame. For instance fouling in condenser tubes would gradually increase chiller power consumption due to higher lost work resulting from greater entropy generation in condenser. 


\section{ACCEPTED MANUSCRIPT}

\section{CONCLUSIONS}

This study demonstrates on how the irreversibility in each component of chiller contributes to overall power consumption. Based on this irreversibility analysis, performance of each component of vapor compression chiller can be continuously monitored to detect faults or abnormalities. 


\section{ACCEPTED MANUSCRIPT}

\section{NOMENCLATURE}

$\mathrm{C}_{p} \quad$ Specific heat, $\mathrm{kJ} / \mathrm{kg} . \mathrm{K}$

h Enthalpy, $\mathrm{kJ} / \mathrm{kg}$

$\dot{m} \quad$ Mass flow rate, $\mathrm{kg} / \mathrm{s}$

$\dot{Q} \quad$ Heat Load, $\mathrm{kW}$

S Entropy, $\mathrm{kJ} / \mathrm{kg} \cdot \mathrm{K}$

S Total entropy rate, $\mathrm{kJ} / \mathrm{K}$

$\dot{S}_{g e n} \quad$ Entropy generation, $\mathrm{kW} / \mathrm{K}$

Temperature, ${ }^{\circ} \mathrm{C}$ or $\mathrm{K}$

$T_{\text {ambient }} \quad$ Ambient temperature, ${ }^{\circ} \mathrm{C}$ or $\mathrm{K}$

$T_{\text {cool }} \quad$ Cooling water reference temperature, ${ }^{\circ} \mathrm{C}$ or $\mathrm{K}$

$\mathrm{T}_{\mathrm{C}, \text { outlet }} \quad$ Chilled water inlet temperature, ${ }^{\circ} \mathrm{C}$ or $\mathrm{K}$

$T_{\text {evap }}^{\text {in }} \quad$ Chilled water inlet temperature, ${ }^{\circ} \mathrm{C}$ or $\mathrm{K}$

$T_{\text {cond }}^{\text {in }} \quad$ Cooling water inlet temperature, ${ }^{\circ} \mathrm{C}$ or $\mathrm{K}$

$T_{H, \text { inlet }} \quad$ Cooling water inlet temperature, ${ }^{\circ} \mathrm{C}$ or $\mathrm{K}$

$T_{R} \quad$ Chill water reference temperature, ${ }^{\circ} \mathrm{C}$ or $\mathrm{K}$ 


\section{ACCEPTED MANUSCRIPT}

$\dot{W} \quad$ Compressor electrical power, $\mathrm{kW}$

Subscripts

c cool

cond condenser

evap evaporator

gen generation

h hot

ref refrigerant 


\section{ACCEPTED MANUSCRIPT}

\section{REFERENCES}

[1] American Society of Heating, Refrigerating and Air-Conditioning Engineers, ASHRAE Fundamentals Handbook (SI) Chapter 1: Thermodynamics and Refrigeration Cycles, American Society of Heating, Refrigeration and Air-Conditioning Engineers, Atlanta, 2009.

[2] Akau, R.L., and Schoenhals, R.J., The Second Law Efficiency of a Heat Pump System, Energy, vol.5, pp. 853-863, 1980.

[3] Cengel, Y.A., and Boles, M.A., Thermodynamics An Engineering Approach 4th Edition, McGraw-Hill Higher Education, Boston, 2001.

[4] Sekulicá, D. P., Entropy Generation in a Heat Exchanger, Heat Transfer Engineering, vol. 7, Iss. 1-2, pp. 83-88, 1986.

[5] Gordon, J.M. and Ng, K.C., Cool Thermodynamics, Cambridge International Scientific Publishers, Cambridge, UK, 2000.

[6] Ogulata, R.T., Doba, F., Yilmaz, T., Second-Law and Experimental Analysis of a Cross-Flow Heat Exchanger, Heat Transfer Engineering, vol. 20, Iss. 2, pp. 20-27, 1999.

[7] Saththasivam, J. and Ng, K.C., Predictive and Diagnostic Methods for Centrifugal Chillers, ASHRAE Transactions, vol 114, part 1, pp. 282-287, 2008.

[8] Stylianou, M. and D. Nikanpour, 1996. Performance monitoring, fault detection and diagnosis of reciprocating chillers, ASHRAE Transactions, vol. 102, part 1, pp. 615-627, 1996. 


\section{ACCEPTED MANUSCRIPT}

Table 1 Chiller Test matrix

\begin{tabular}{|c|c|c|c|}
\hline $\begin{array}{c}\text { Set } \\
\text { Point }\end{array}$ & $\begin{array}{c}\text { Frequency } \\
(\mathrm{Hz})\end{array}$ & $\begin{array}{c}T_{\text {C,outlet }} \\
(\mathrm{K})\end{array}$ & $\begin{array}{c}T_{H, \text { inlet }} \\
(\mathrm{K})\end{array}$ \\
\hline 1 & 50 & 8.0 & 28.0 \\
\hline 2 & 50 & 7.0 & 28.0 \\
\hline 3 & 50 & 6.0 & 28.0 \\
\hline 4 & 50 & 6.7 & 29.4 \\
\hline 5 & 50 & 6.0 & 30.0 \\
\hline 6 & 50 & 8.0 & 30.0 \\
\hline 7 & 50 & 9.0 & 30.0 \\
\hline 8 & 50 & 9.0 & 32.0 \\
\hline 9 & 50 & 8.0 & 32.0 \\
\hline 10 & 50 & 6.0 & 32.0 \\
\hline
\end{tabular}

\begin{tabular}{|c|c|c|c|}
\hline $\begin{array}{c}\text { Set } \\
\text { Point }\end{array}$ & $\begin{array}{c}\text { Frequency } \\
(\mathrm{Hz})\end{array}$ & $\begin{array}{c}T_{C, \text { outlet }} \\
(\mathrm{K})\end{array}$ & $\begin{array}{c}T_{H, \text { inlet }} \\
(\mathrm{K})\end{array}$ \\
\hline 11 & 35 & 8.0 & 28.0 \\
\hline 12 & 35 & 7.0 & 28.0 \\
\hline 13 & 35 & 6.0 & 28.0 \\
\hline 14 & 35 & 6.7 & 29.4 \\
\hline 15 & 35 & 6.0 & 30.0 \\
\hline 16 & 35 & 8.0 & 30.0 \\
\hline 17 & 35 & 9.0 & 30.0 \\
\hline 18 & 35 & 9.0 & 32.0 \\
\hline 19 & 35 & 8.0 & 32.0 \\
\hline 20 & 35 & 6.0 & 32.0 \\
\hline
\end{tabular}




\section{ACCEPTED MANUSCRIPT}

Table 2 Calculation of entropy generation for each chiller component

\begin{tabular}{|c|c|c|c|c|c|c|c|c|}
\hline $\begin{array}{l}\text { Po } \\
\text { int }\end{array}$ & $\begin{array}{l}\text { Ref Mass } \\
\text { Flow, kg/s }\end{array}$ & $\begin{array}{c}\dot{S}_{g e n, 71} \\
\text { Evaporator } \\
\text { kW/K }\end{array}$ & $\begin{array}{c}\dot{Q}_{12} \\
\text { Suction } \\
\mathrm{kW}\end{array}$ & $\begin{array}{l}\dot{S}_{g e n, 12} \\
\text { Suction } \\
\text { kW/K }\end{array}$ & $\begin{array}{c}\dot{Q}_{23} \\
\text { Compre } \\
\text { ssor } \\
\mathrm{kW}\end{array}$ & $\begin{array}{c}\dot{S}_{\text {gen,23 }} \text { Co } \\
\text { mpressor } \\
\text { kW/K }\end{array}$ & $\begin{array}{c}\dot{Q}_{34} \\
\text { Discharge } \\
\mathrm{kW}\end{array}$ & $\begin{array}{c}\dot{S}_{g e n, 34} \mathrm{D} \\
\text { ischarge } \\
\mathrm{kW} / \mathrm{K}\end{array}$ \\
\hline 1 & 0.097 & $1.844 \mathrm{E}-03$ & 0.04 & $\begin{array}{c}1.292 \mathrm{E}- \\
05\end{array}$ & -0.57 & $5.030 \mathrm{E}-03$ & -0.09 & $\begin{array}{c}1.216 \mathrm{E}- \\
04\end{array}$ \\
\hline 2 & 0.094 & $1.820 \mathrm{E}-03$ & 0.03 & $\begin{array}{c}3.194 \mathrm{E}- \\
05\end{array}$ & -0.60 & $5.035 \mathrm{E}-03$ & -0.09 & $\begin{array}{c}1.137 \mathrm{E}- \\
04\end{array}$ \\
\hline 3 & 0.090 & $1.761 \mathrm{E}-03$ & 0.03 & $\begin{array}{c}\text { 7.024E- } \\
06\end{array}$ & -0.57 & $5.078 \mathrm{E}-03$ & -0.09 & $\begin{array}{c}1.068 \mathrm{E}- \\
04\end{array}$ \\
\hline 4 & 0.092 & $1.786 \mathrm{E}-03$ & 0.03 & $\begin{array}{c}1.145 \mathrm{E}- \\
05\end{array}$ & -0.62 & $5.272 \mathrm{E}-03$ & -0.10 & $\begin{array}{c}1.257 \mathrm{E}- \\
04\end{array}$ \\
\hline 5 & 0.090 & $1.730 \mathrm{E}-03$ & 0.03 & $\begin{array}{c}2.559 \mathrm{E}- \\
05\end{array}$ & -0.58 & $5.293 \mathrm{E}-03$ & -0.10 & $\begin{array}{c}1.279 \mathrm{E}- \\
04\end{array}$ \\
\hline 6 & 0.097 & $1.822 \mathrm{E}-03$ & 0.06 & $\begin{array}{c}2.144 \mathrm{E}- \\
05\end{array}$ & -0.60 & $5.263 \mathrm{E}-03$ & -0.10 & $\begin{array}{c}1.392 \mathrm{E}- \\
04\end{array}$ \\
\hline 7 & 0.100 & $1.859 \mathrm{E}-03$ & 0.02 & $\begin{array}{c}3.368 \mathrm{E}- \\
05\end{array}$ & -0.65 & $5.432 \mathrm{E}-03$ & -0.10 & $\begin{array}{c}1.409 \mathrm{E}- \\
04\end{array}$ \\
\hline 8 & 0.100 & $1.769 \mathrm{E}-03$ & 0.02 & $\begin{array}{c}1.642 \mathrm{E}- \\
05\end{array}$ & -0.69 & $5.690 \mathrm{E}-03$ & -0.11 & $\begin{array}{c}1.172 \mathrm{E}- \\
04\end{array}$ \\
\hline 9 & 0.097 & $1.781 \mathrm{E}-03$ & 0.07 & $\begin{array}{c}1.073 \mathrm{E}- \\
05\end{array}$ & -0.64 & $5.538 \mathrm{E}-03$ & -0.11 & $\begin{array}{c}1.172 \mathrm{E}- \\
04\end{array}$ \\
\hline
\end{tabular}




\section{ACCEPTED MANUSCRIPT}

\begin{tabular}{|c|c|c|c|c|c|c|c|c|}
\hline 10 & 0.089 & $1.731 \mathrm{E}-03$ & 0.04 & $\begin{array}{c}4.685 \mathrm{E}- \\
05\end{array}$ & -0.62 & $5.571 \mathrm{E}-03$ & -0.11 & $\begin{array}{c}1.265 \mathrm{E}- \\
04\end{array}$ \\
\hline 11 & 0.071 & $1.134 \mathrm{E}-03$ & 0.00 & $\begin{array}{c}8.815 \mathrm{E}- \\
05\end{array}$ & -0.53 & $3.556 \mathrm{E}-03$ & -0.07 & $\begin{array}{c}4.501 \mathrm{E}- \\
05\end{array}$ \\
\hline 12 & 0.068 & $1.069 \mathrm{E}-03$ & 0.01 & $\begin{array}{c}7.176 \mathrm{E}- \\
05\end{array}$ & -0.47 & $3.355 \mathrm{E}-03$ & -0.06 & $\begin{array}{c}6.041 \mathrm{E}- \\
05\end{array}$ \\
\hline 13 & 0.066 & $1.038 \mathrm{E}-03$ & 0.03 & $\begin{array}{c}7.823 \mathrm{E}- \\
05\end{array}$ & -0.48 & $3.408 \mathrm{E}-03$ & -0.06 & $\begin{array}{c}\text { 6.305E- } \\
05\end{array}$ \\
\hline 14 & 0.068 & $1.062 \mathrm{E}-03$ & 0.02 & $\begin{array}{c}6.705 \mathrm{E}- \\
05\end{array}$ & -0.50 & $3.458 \mathrm{E}-03$ & -0.07 & $\begin{array}{c}\text { 7.799E- } \\
05\end{array}$ \\
\hline 15 & 0.066 & $1.020 \mathrm{E}-03$ & 0.04 & $\begin{array}{c}7.589 \mathrm{E}- \\
05\end{array}$ & -0.52 & $3.594 \mathrm{E}-03$ & -0.07 & $\begin{array}{c}\text { 7.979E- } \\
05\end{array}$ \\
\hline 16 & 0.070 & $1.054 \mathrm{E}-03$ & 0.03 & $\begin{array}{c}3.155 \mathrm{E}- \\
05\end{array}$ & -0.52 & $3.581 \mathrm{E}-03$ & -0.07 & $\begin{array}{c}8.204 \mathrm{E}- \\
05\end{array}$ \\
\hline 17 & 0.072 & $1.073 \mathrm{E}-03$ & 0.01 & $\begin{array}{c}8.804 \mathrm{E}- \\
05\end{array}$ & -0.51 & $3.585 \mathrm{E}-03$ & -0.07 & $\begin{array}{c}6.532 \mathrm{E}- \\
05\end{array}$ \\
\hline 18 & 0.072 & $1.068 \mathrm{E}-03$ & 0.01 & $\begin{array}{c}8.994 \mathrm{E}- \\
05\end{array}$ & -0.54 & $3.784 \mathrm{E}-03$ & -0.08 & $\begin{array}{c}8.690 \mathrm{E}- \\
05\end{array}$ \\
\hline 19 & 0.069 & $1.023 \mathrm{E}-03$ & 0.03 & $\begin{array}{c}3.368 \mathrm{E}- \\
06\end{array}$ & -0.54 & $3.722 \mathrm{E}-03$ & -0.07 & $\begin{array}{c}5.638 \mathrm{E}- \\
05\end{array}$ \\
\hline 20 & 0.066 & $9.833 \mathrm{E}-04$ & 0.04 & $\begin{array}{c}6.355 \mathrm{E}- \\
05\end{array}$ & -0.56 & 3.836E-03 & -0.08 & $\begin{array}{c}7.348 \mathrm{E}- \\
05\end{array}$ \\
\hline
\end{tabular}




\section{ACCEPTED MANUSCRIPT}

Table 2 (continuation)

\begin{tabular}{|c|c|c|c|c|c|c|}
\hline $\begin{array}{c}\text { Poin } \\
\mathrm{t}\end{array}$ & $\begin{array}{c}\dot{Q}_{45} \\
\text { Condenser } \\
\mathrm{kW}\end{array}$ & $\begin{array}{c}\dot{S}_{g e n, 45} \text { Condens } \\
\text { er } \\
\mathrm{kW} / \mathrm{K}\end{array}$ & $\begin{array}{c}\dot{Q}_{56} \text { Liquid } \\
\text { Line } \\
\mathrm{kW}\end{array}$ & $\begin{array}{c}\dot{S}_{g e n, 56} \text { Liquid } \\
\text { Line } \\
\mathrm{kW} / \mathrm{K}\end{array}$ & $\begin{array}{c}\dot{S}_{g e n, 67} \operatorname{Exp} \\
\text { Valve } \\
\text { kW/K }\end{array}$ & $\begin{array}{c}\dot{S}_{\text {gen,Total }} \text { Chill } \\
\text { er } \\
\mathrm{kW} / \mathrm{K}\end{array}$ \\
\hline 1 & -19.38 & $3.321 \mathrm{E}-03$ & -0.11 & $1.696 \mathrm{E}-05$ & $1.374 \mathrm{E}-03$ & $1.172 \mathrm{E}-02$ \\
\hline 2 & -18.88 & $3.172 \mathrm{E}-03$ & -0.09 & $2.272 \mathrm{E}-05$ & $1.407 \mathrm{E}-03$ & $1.160 \mathrm{E}-02$ \\
\hline 3 & -18.17 & $3.003 \mathrm{E}-03$ & -0.10 & $2.035 \mathrm{E}-05$ & $1.365 \mathrm{E}-03$ & $1.134 \mathrm{E}-02$ \\
\hline 4 & -18.46 & $3.035 \mathrm{E}-03$ & -0.11 & $3.235 \mathrm{E}-05$ & $1.441 \mathrm{E}-03$ & $1.170 \mathrm{E}-02$ \\
\hline 5 & -18.13 & $2.943 \mathrm{E}-03$ & -0.11 & $2.155 \mathrm{E}-05$ & $1.489 \mathrm{E}-03$ & $1.163 \mathrm{E}-02$ \\
\hline 6 & -19.28 & $3.261 \mathrm{E}-03$ & -0.12 & $1.043 \mathrm{E}-05$ & $1.509 \mathrm{E}-03$ & $1.202 \mathrm{E}-02$ \\
\hline 7 & -19.85 & $3.424 \mathrm{E}-03$ & -0.12 & $1.482 \mathrm{E}-05$ & $1.519 \mathrm{E}-03$ & $1.242 \mathrm{E}-02$ \\
\hline 8 & -19.70 & $3.338 \mathrm{E}-03$ & -0.13 & $2.892 \mathrm{E}-05$ & $1.670 \mathrm{E}-03$ & $1.263 \mathrm{E}-02$ \\
\hline 9 & -19.16 & $3.211 \mathrm{E}-03$ & -0.13 & $1.230 \mathrm{E}-05$ & $1.598 \mathrm{E}-03$ & $1.227 \mathrm{E}-02$ \\
\hline 10 & -17.94 & $2.916 \mathrm{E}-03$ & -0.10 & $2.416 \mathrm{E}-05$ & $1.579 \mathrm{E}-03$ & $1.199 \mathrm{E}-02$ \\
\hline 11 & -13.94 & $1.809 \mathrm{E}-03$ & -0.07 & $2.215 \mathrm{E}-06$ & 8.091E-04 & 7.439E-03 \\
\hline 12 & -13.53 & $1.668 \mathrm{E}-03$ & -0.07 & $1.485 \mathrm{E}-05$ & $8.217 \mathrm{E}-04$ & $7.061 \mathrm{E}-03$ \\
\hline 13 & -13.10 & $1.572 \mathrm{E}-03$ & -0.06 & $1.765 \mathrm{E}-05$ & $8.214 \mathrm{E}-04$ & $6.999 \mathrm{E}-03$ \\
\hline 14 & -13.35 & $1.616 \mathrm{E}-03$ & -0.07 & $1.189 \mathrm{E}-05$ & $8.650 \mathrm{E}-04$ & $7.158 \mathrm{E}-03$ \\
\hline 15 & -13.04 & $1.554 \mathrm{E}-03$ & -0.07 & $2.711 \mathrm{E}-05$ & $8.903 \mathrm{E}-04$ & $7.241 \mathrm{E}-03$ \\
\hline 16 & -13.78 & $1.728 \mathrm{E}-03$ & -0.07 & $6.388 \mathrm{E}-06$ & $8.946 \mathrm{E}-04$ & $7.378 \mathrm{E}-03$ \\
\hline 17 & -14.13 & $1.835 \mathrm{E}-03$ & -0.07 & $2.597 \mathrm{E}-05$ & $9.284 \mathrm{E}-04$ & $7.550 \mathrm{E}-03$ \\
\hline 18 & -14.03 & $1.762 \mathrm{E}-03$ & -0.08 & $1.351 \mathrm{E}-05$ & $9.568 \mathrm{E}-04$ & 7.761E-03 \\
\hline 19 & -13.59 & $1.681 \mathrm{E}-03$ & -0.07 & $2.707 \mathrm{E}-05$ & $9.328 \mathrm{E}-04$ & $7.446 \mathrm{E}-03$ \\
\hline 20 & -12.94 & $1.532 \mathrm{E}-03$ & -0.07 & $2.879 \mathrm{E}-05$ & $9.584 \mathrm{E}-04$ & $7.476 \mathrm{E}-03$ \\
\hline
\end{tabular}




\section{ACCEPTED MANUSCRIPT}

Table 3 Compressor power prediction from the lost work

\begin{tabular}{|c|c|c|c|c|c|c|c|c|}
\hline Point & $\begin{array}{c}T_{\text {ambient }} \\
\mathrm{K}\end{array}$ & $\begin{array}{c}\begin{array}{c}\dot{S} \text { gen, } \\
\text { Total } \\
\mathrm{kW} / \mathrm{K}\end{array} \\
(\mathrm{E}-02)\end{array}$ & $\begin{array}{c}T_{H, \text { outlet }} \\
\text { Carnot } \\
\mathrm{K}\end{array}$ & $\begin{array}{c}\dot{W}_{\text {reversible }} \\
\mathrm{kW}\end{array}$ & $\begin{array}{c}\dot{W}_{\text {Lost work }} \\
\mathrm{kW}\end{array}$ & $\begin{array}{c}\text { Predicted } \\
\text { Power } \\
\text { kW }\end{array}$ & $\begin{array}{c}\text { Actual } \\
\text { Power } \\
\text { kW }\end{array}$ & $\begin{array}{c}\text { Diff } \\
\%\end{array}$ \\
\hline 1 & 295.3 & 1.172 & 306.0 & 1.16 & 3.46 & 4.62 & 4.61 & 0.2 \\
\hline 2 & 296.0 & 1.160 & 305.9 & 1.18 & 3.43 & 4.61 & 4.59 & 0.4 \\
\hline 3 & 295.2 & 1.134 & 305.7 & 1.19 & 3.35 & 4.53 & 4.53 & 0.1 \\
\hline 4 & 295.3 & 1.170 & 307.1 & 1.24 & 3.46 & 4.70 & 4.69 & 0.1 \\
\hline 5 & 295.2 & 1.163 & 307.6 & 1.29 & 3.43 & 4.73 & 4.71 & 0.3 \\
\hline 6 & 295.2 & 1.202 & 308.0 & 1.27 & 3.55 & 4.81 & 4.80 & 0.3 \\
\hline 7 & 295.2 & 1.242 & 308.1 & 1.25 & 3.67 & 4.92 & 4.90 & 0.4 \\
\hline 8 & 295.3 & 1.263 & 310.1 & 1.36 & 3.73 & 5.09 & 5.08 & 0.2 \\
\hline 9 & 295.2 & 1.227 & 309.9 & 1.38 & 3.62 & 5.00 & 5.00 & 0.0 \\
\hline 10 & 297.8 & 1.199 & 309.6 & 1.36 & 3.57 & 4.93 & 4.90 & 0.6 \\
\hline 11 & 295.9 & 0.744 & 304.8 & 0.85 & 2.20 & 3.05 & 3.00 & 1.8 \\
\hline 12 & 295.9 & 0.706 & 304.7 & 0.87 & 2.09 & 2.95 & 2.91 & 1.5 \\
\hline 13 & 295.8 & 0.700 & 304.6 & 0.88 & 2.07 & 2.95 & 2.90 & 1.6 \\
\hline 14 & 295.6 & 0.716 & 306.0 & 0.92 & 2.12 & 3.04 & 3.00 & 1.3 \\
\hline 15 & 299.3 & 0.724 & 306.5 & 0.93 & 2.17 & 3.10 & 3.05 & 1.5 \\
\hline 16 & 300.5 & 0.738 & 306.8 & 0.90 & 2.22 & 3.12 & 3.10 & 0.6 \\
\hline 17 & 300.4 & 0.760 & 306.8 & 0.89 & 2.28 & 3.17 & 3.10 & 2.2 \\
\hline
\end{tabular}




\section{ACCEPTED MANUSCRIPT}

\begin{tabular}{|c|c|c|c|c|c|c|c|c|}
\hline 18 & 300.1 & 0.776 & 308.7 & 0.96 & 2.33 & 3.29 & 3.24 & 1.7 \\
\hline 19 & 299.9 & 0.745 & 308.6 & 0.97 & 2.23 & 3.20 & 3.20 & 0.1 \\
\hline 20 & 299.5 & 0.748 & 308.5 & 1.00 & 2.24 & 3.24 & 3.20 & 1.2 \\
\hline
\end{tabular}




\section{ACCEPTED MANUSCRIPT}

\section{List of Figure Captions}

Figure 1 Thermodynamic state points required for entropy generation calculation

Figure 2 Reverse Carnot Cycle

Figure 3 Schematic diagram of the coolant system

Figure 4 Pressure $(\mathrm{P})$ and temperature $(\mathrm{T})$ sensors locations in the refrigerant system

Figure 5 Prediction accuracy of chiller power consumption 


\section{ACCEPTED MANUSCRIPT}

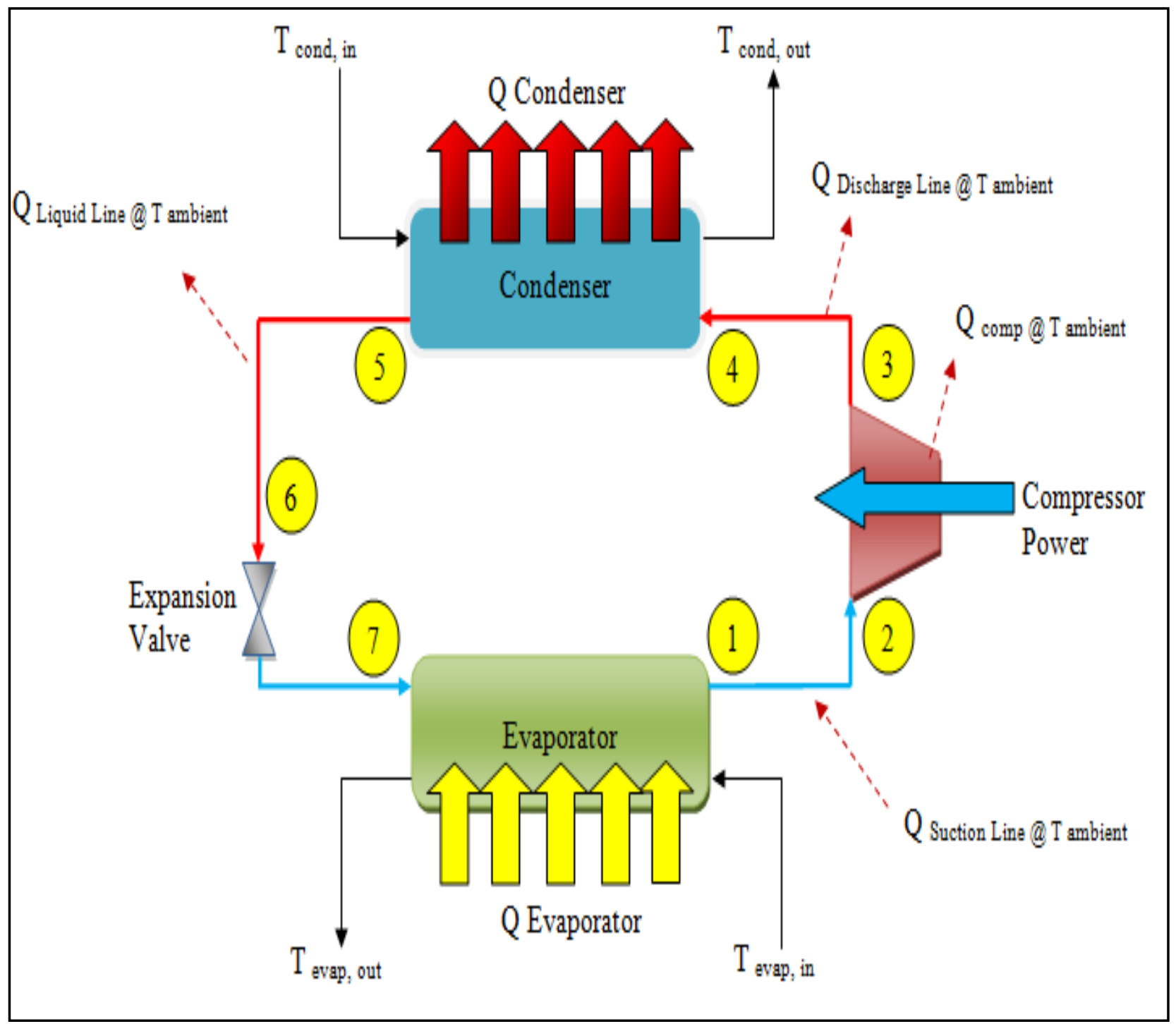

Figure 1 Thermodynamic state points required for entropy generation calculation 


\section{ACCEPTED MANUSCRIPT}

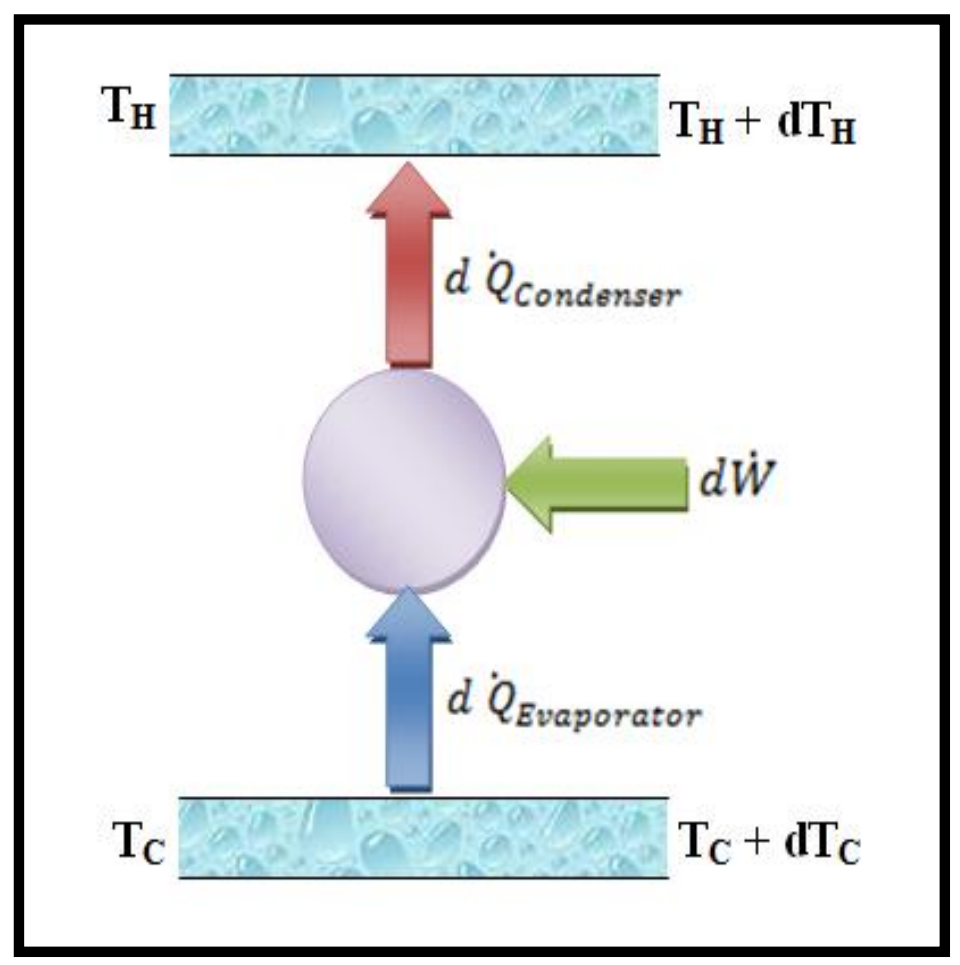

Figure 2 Reverse Carnot Cycle 


\section{ACCEPTED MANUSCRIPT}

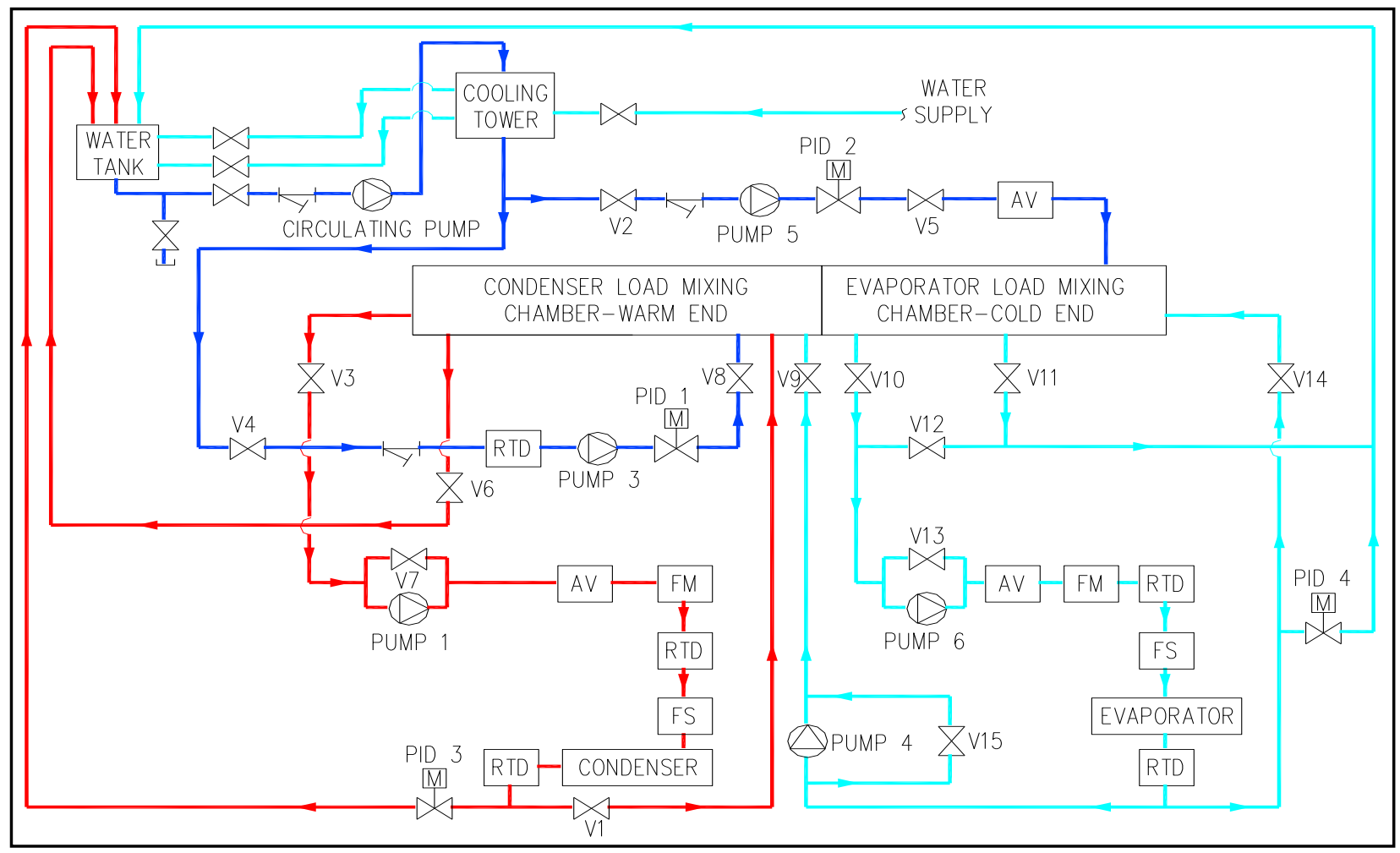

Figure 3 Schematic diagram of the coolant system 


\section{ACCEPTED MANUSCRIPT}

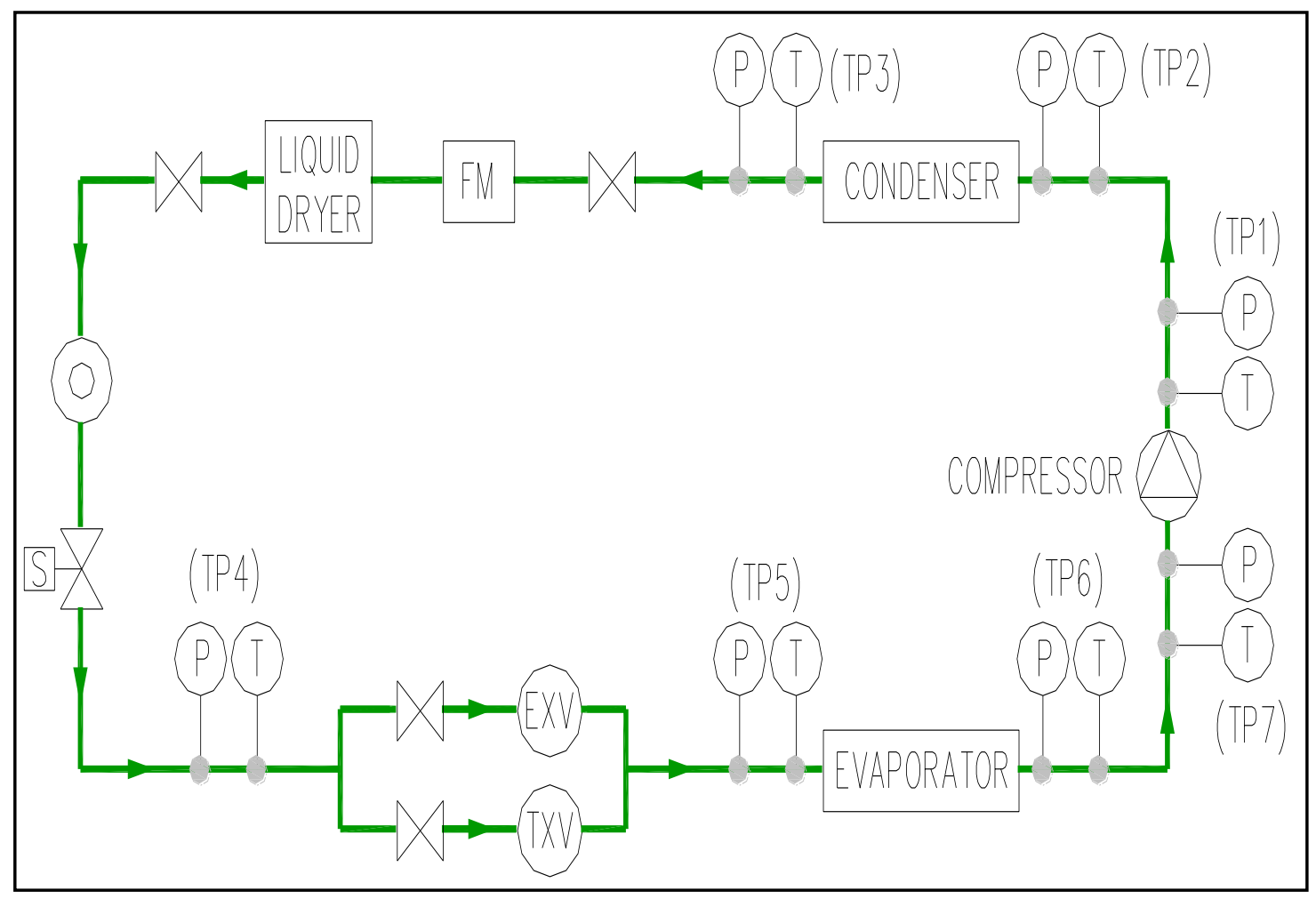

Figure 4 Pressure $(\mathrm{P})$ and temperature $(\mathrm{T})$ sensors locations in the refrigerant system 


\section{ACCEPTED MANUSCRIPT}

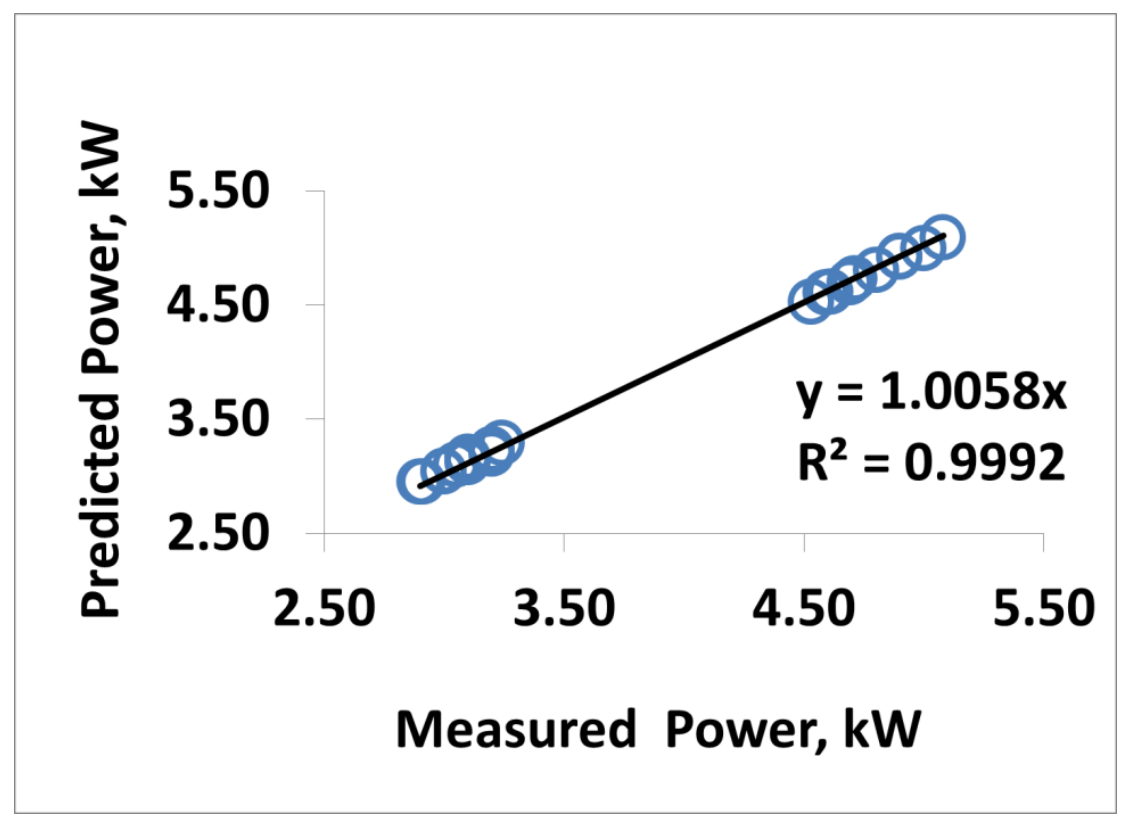

Figure 5 Prediction accuracy of chiller power consumption 


\section{ACCEPTED MANUSCRIPT}

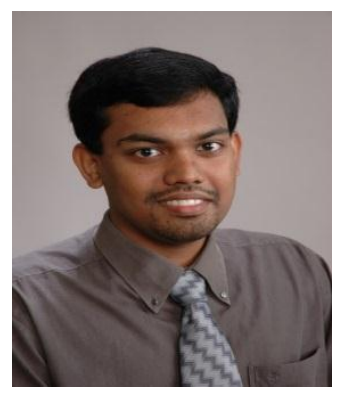

Jayaprakash Saththasivam graduated with First Class Honors (Mechanical-Aeronautics Engineering) from University Teknologi Malaysia in 2005. He obtained his Ph.D. in Mechanical Engineering from National University of Singapore in 2011. Prior to joining Qatar Environment and Energy Research Institute (QEERI) as a Scientist, he worked in Malaysia, Singapore and Saudi Arabia. In QEERI, his research mainly focuses on energy recovery and water treatment related processes.

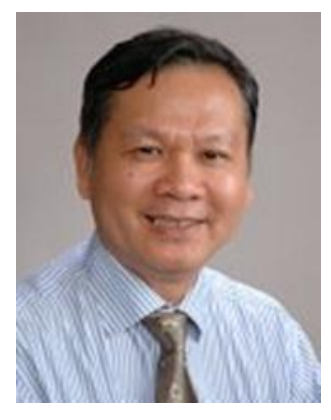

Kim Choon Ng obtained his B.Sc. (Hons.) and Ph.D. from Strathclyde University in Glasgow, UK, in 1975 and 1980, respectively. He worked briefly at the Babcock Power Ltd. in Renfrew prior to joining in 1981the Department of Mechanical Engineering of the National University of Singapore, where he is now a tenured professor. His areas of research are two-phase flow, chiller testing and modeling, electro-adsorption chillers, and renewable energy. To date, he has written more than 200 peer-reviewed journal and international conference articles, six patents, and co-authored a book, Cool Thermodynamics, printed by CISP (UK). He is a member of the IMechE (UK) and the Institution of Engineers Singapore, a chartered engineer (UK) and a registered professional engineer (S), and an associate editor of Heat Transfer Engineering and of Proceedings of the Institution of Mechanical Engineers, Part E, Journal of Process Mechanical Engineering. He also serves as an editorial board member for Advances in Mechanical Engineering. 